\title{
EFFECT OF COMBINATION OF YEAST (Saccharomyces cerevisae + Candida utilis) AND HERBS SUPPLEMENTATION IN FINISHING DIET ON CARCASS CHARACTERISTICS OF BEEF CATTLE
}

\author{
P. Mahyuddin and M.Winugroho \\ Indonesia Research Institute for Animal Production, \\ PO Box 221 Bogor 16002 - Indonesia \\ Corresponding E-mail: pmahyuddin@yahoo.com \\ Received November 02, 2010; Accepted November 28, 2010
}

\begin{abstract}
A 75 days feeding trial was completed to study the effect of inclusion of a combined probiotic yeast+herbs in finishing diet on carcass characteristics of beef cattle. Thirty bull of Ongole crossbred, age 2.5-3 years old with average body weight $(\mathrm{BW})$ of $320 \mathrm{~kg}$ were used in this experiment. They were divided into 2 groups, each of 15 animals and were allotted to control and treatment. They were slaughtered at around $450 \mathrm{~kg}$ BW. The treated animals were given a supplementation containing combined yeast (Saccharomyces cerevisae and Candida utilis) and herbs. All animals were fed a diet of ammoniated rice straw and commercial concentrate with a ratio of 10: 90. Addition of combined probiotics + herbs in the diet increased percentage of carcass, dressing and meat, but there were no effect on live weight gain (LWG), \% bone, meat:bone ratio, \% body fat, back fat thickness and eye muscle area. There was a reduction in the percentage of offal due to a decrease in intestinal weight in the treated animal.
\end{abstract}

Keywords: Cattle, Carcass, Herbs, Yeast

\section{INTRODUCTION}

Yeast cultures based on Saccharomyces cerevisae are widely used as feed additive in ruminant diet since the global concern over the use of antibiotics and growth promoters in feed for food production. Yeast supplementation may be beneficial in feedlot where diet is switched from forage-based to grain-based and ruminal acidosis continues to be a common ruminal digestive disorder. Several studies have indicated that live yeasts are capable to stabilize rumen $\mathrm{pH}$ under subacute rumen acidosis which can develop rapidly to acute acidosis if the circumstances deteriorate (Chayucheryas-Durand et al., 2008). The most consistent results observed with supplementation of yeast in ruminants is an increase in the number of rumen bacterial cells (Newbold et al., 1998). A number of mechanisms have been proposed how small amounts of yeast can stimulate microbial numbers in the rumen (Newbold et al., 1996; Jouany and Morgavi, 2007; Chaucheryas-Durand et al., 2008). Furthermore, Erasmus et al. (1992) indicated that Saccharomyces cerevisae supplementation was associated with an increased flow of microbial protein leaving the rumen and enhanced supply of amino acids entering the small intestine. Therefore, it is likely that addition of yeast in the diet, will have beneficial effect on milk and meat production.

Inclusion of yeast culture in the diet produced variable responses in animal performance, even with the same yeast culture preparation, the response may range from lack of effect to positive effect (Denev et al., 2009). Feeding yeast culture has no effect on dry matter intake (DMI), live weight gain (LWG) or feed conversion ratio (FCR) of steers (Cabrera et al., 2000; Gomes et al., 2009), buffalo (Mahyuddin and Widiawati, 2010), male dairy calves (Titi et al., 2008b) or finishing lambs (Kawas et al., 2007a; Kawas et al., 2007b; Titi et al, 2008a) and kids (Titi et al, 2008a), goats (Whitley et al., 2009) or buffalo calves (Ramirez et al., 2007). However, Haddad and Goussous (2005) and Tripathy et al., (2010) found supplementation of yeast culture in lambs increased LWG, DMI, and DM digestibility in yeast-supplemented lambs observed by Haddad and Goussous (2005), but were not found by Tripathy et al. (2010).

The response to yeast supplementation on 
carcass characteristics were also variable; no improvement of carcass traits and meat quality of feedlot finished steers (Mir and Mir, 1994; Hinmann et al., 1998; Gomes et al., 2009), or finished goats (Whitley et al., 2009; Titi et al., 2008a). Addition of yeast culture in finish diet reduced meat/bone ratio and tissue protein in lambs and goats, increased fat content in lambs but not in goats (Titi et al., 2008a).

Chaucherys-Durand et al. (2008) concluded that the effects of yeast supplementation vary depending on factors such as strain of yeast and its viability, nature of the diet or animal management. In South East Asia, the smallholders have been using herbs as feed supplement to prevent or cure animal disease. The popular one is Curcuma sp which contain antibacterial curcumine and Alpina galanga which is believed to improve appetite.

The aim of the present paper was to evaluate the effect of combination of yeast (Saccharomyces cerevisae + Candida utilis) and herbs in finishing diet on carcass characteristics of beef cattle.

\section{MATERIALS AND METHODS}

\section{Animals, Experimental Procedures and Treatment Diets}

Thirty Ongole crossed bulls aged $2.5-3$ years were divided into 2 groups using stratified body weight (BW). The mean of initial body weight of each group was $323 \mathrm{~kg}$. Each group (15 animals) was placed in a shaded paddock for 75 days to reach a slaughter weight of $400-450 \mathrm{~kg}$. The groups were the control and the treatment. All animals received the same ration (Table 1) ad libitum 2 times a day. At the start the animals were offered a diet consisting of 1: 1 (ammoniated rice straw: concentrate) and gradually this ratio was increased to 1: 9. The treatment group was offered with an additional probiotics and herbs as supplement. Total of the feed offered and refused were recorded daily.

The probiotics used in this experiment were Saccharomyces cerevisae $\left(2.4 \times 10^{6} \mathrm{cfu} / \mathrm{g}\right)$ and Candida utilis $\left(15 \times 10^{11} \mathrm{cfu} / \mathrm{g}\right)$ each was added to the diet at a rate of $15 \mathrm{~g} / \mathrm{head} / \mathrm{d}$. The composition of herbal was: 4\% Curcuma longa tuber, $4 \%$ Curcuma xanthorrhiza tuber, 4\% Alpina galanga tuber, 3.2\% Antidesma bunius leaves, 4\% Zingiber aromaticum tuber, 3.2\% Curcuma longa leaf organic $\mathrm{Zn}(0.17 \%)$, organic $\mathrm{Cu}(0.17 \%)$ and rice bran $(77.3 \%)$.

The composition of organic $\mathrm{Zn}$ was soyabean meal (69.4\%), $\mathrm{ZnSO} 4(27.8 \%)$ and $S$. cerevisae $(2.8 \%)$. The composition of organic $\mathrm{Cu}$ was soyabean meal (60.4\%), CuSO4 (27.8\%) and $S$. cerevisae $(2.8 \%)$. Both of these organic minerals were fermented for 24 days. The herbal was added to the diet at the rate of $125 \mathrm{~g} / \mathrm{head} / \mathrm{d}$.

Each animal was weighed at the start of fattening and before slaughtering after a 12-h period of fasting. Immediately after slaughtering, the right side was quartered and the hind quarter was dissected into deboned and trimmed commercial joints, following the local butchering procedure.

\section{Chemical Analysis}

Chemical analyses were done according to AOAC (1990). In vitro organic matter digestibility of ammoniated rice straw and concentrate were determined using the method of Tilley and Terry (1963) to calculate metabolizable energy (ME) content, $\mathrm{ME}=0.15 \% \mathrm{DOM}$

Meat sample was taken from longissimus dorsi between $12^{\text {th }}$ and $13^{\text {th }}$ rib for rib eye area determination and sample of sirloin was taken for proximate analysis and fatty acid composition. Fatty acid analysis was done by HighPerformance Liquid Chromatography (HPLC).

Table 1. Dietary Ingredients and Composition of the Feedlot Diet (DM bas is )

\begin{tabular}{lc}
\hline \multicolumn{1}{c}{ Dietary Ingredients } & Percentage \\
\hline Ammoniated rice straw & 100 \\
Rice straw & 1 \\
NaCl & 3 \\
Urea & 10 \\
Molases & 25 \\
Water & \\
\hline Concentrate & 5.7 \\
Copra meal & 24 \\
Palm kernel cake & 32 \\
Pollard & 28.8 \\
Cassava waste & 7 \\
Rice bran & 0.8 \\
Urea & 0.5 \\
NaCl & 0.7 \\
CaCO3 & 0.2 \\
NaHCO3 & 0.2 \\
Vitamin+mineral (Premix) & \\
\hline
\end{tabular}


Table 2. Chemical Composition of Ammoniated Rice Straw and Concentrate

\begin{tabular}{lcc}
\hline \multicolumn{1}{c}{ Item } & $\begin{array}{c}\text { Ammoniated } \\
\text { Rice Straw }\end{array}$ & Concentrate \\
\hline DM (\%) & 65 & 89.7 \\
Crude protein (\%) & 9.1 & 12.3 \\
NDF (\%) & 78 & 60 \\
Fat (\%) & 0.6 & 5.2 \\
Ca (\%) & 0.13 & 0.5 \\
P (\%) & 0.05 & 0.4 \\
ME (MJ/kg) & 7 & 10.5 \\
\hline
\end{tabular}

\section{Statistical Analysis}

Comparison between control and treated animals were done using t-test (Steel and Torrie, 1980)

\section{RESULTS AND DISCUSSION}

\section{Live weight gain and Dry matter Intake}

The inclusion of combined probiotics (Saccharomyces cerevisae + Candida utilis) and herbs in the diet, did not affect LWG (Table 3).This may be due to the DMI was similar in both control and treated steers. However, there was only one value for DMI for treated and control animals since animals in each group were fed together, therefore could not be used statistically. If the value of DMI is true mean value, then the feed conversion ratios (FCR) were also similar for both control and treated animals. In this experiment the addition of herbs which was supposed to improve appetite did not show the effect on the treated animals. In the previous experiment using male buffalo Mahyuddin and Widiawati (2010) also found similar results. Response to yeast supplementation on growth has been inconsistent. There was no significant improvement on LWG in animal supplemented with yeast culture were also observed by Cabrera et al. (2000), Ramirez et al. (2007), Kawas et al. (2007a) Titi et al. (2008b) and Gomes et al. (2009) whereas Haddad and Goussous (2005) and Tripathi et al. (2010) found increased LWG in lambs treated yeast.

In this study, concentrate was offered at gradual increase up to $90 \%$ in the diet. It seemed that the buffaloes in this study had been well adapted with the high concentrate diet. Beachemin et al. (2003) and Krehbiel et al. (2003) noted that when feedlot cattle are already adapted to high grain diet, despite has low rumen $\mathrm{pH}$, supplementation of direct fed bacterial +/yeast appears to be of limited value. In this experiment, although rumen $\mathrm{pH}$ was not determined, there was no symptom of lactic acidosis being noted in the experimental animals. The supplementation of yeast + herbs was given when the animals were already adapted to the 10:90 ratio of ammonia-treated rice straw:

Table 3. Mean Dry Matter Intake (DMI), Live Weight Gain (LWG), Percentage of Carcass, Dressing Meat, Bone, Meat:Bone Ratio, Body Fat, Offal,

By-product, Back Fat and Eye Muscle Area

\begin{tabular}{lccc}
\hline \multicolumn{1}{c}{ Parameter } & Control & Treatment & Significance \\
\hline DMI $(\mathrm{kg} / \mathrm{d})$ & 10.30 & 10.4 & $\mathrm{~ns}$ \\
LWG $(\mathrm{kg} / \mathrm{d})$ & $1.30 \pm 0.12$ & $1.23 \pm 0.11$ & $\mathrm{~ns}$ \\
Carcass $(\% \mathrm{BW})$ & $47.6 \pm 0.54$ & $50.0 \pm 0.22$ & $*$ \\
Dressing $(\%)$ & $50.8 \pm 0.59$ & $52.9 \pm 0.23$ & $*$ \\
Meat $(\% \mathrm{BW})$ & $24.9 \pm 0.59$ & $26.8 \pm 0.57$ & $*$ \\
Bone $(\% \mathrm{BW})$ & $5.8 \pm 0.21$ & $5.5 \pm 0.24$ & $\mathrm{~ns}$ \\
Meat:Bone & $4.4 \pm 0.18$ & $5.0 \pm 0.29$ & $\mathrm{~ns}$ \\
Body fat $(\% \mathrm{BW})$ & $4.5 \pm 0.64$ & $4.6 \pm 0.31$ & $\mathrm{~ns}$ \\
Offal $(\% \mathrm{BW})$ & $6.2 \pm 0.16$ & $5.4 \pm 0.17$ & $*$ \\
Back fat $(\mathrm{mm})$ & $6.8 \pm 0.57$ & $6.2 \pm 0.37$ & $\mathrm{~ns}$ \\
Eye muscle area $\left(\mathrm{cm}^{2}\right)$ & $56.0 \pm 8.48$ & $57.6 \pm 8.32$ & $\mathrm{~ns}$ \\
\hline
\end{tabular}

Mean values with different superscripts at the same row indicates differ significantly $(P<0.05)$ 
concentrate. Similar explanation may be offered to those studies whereby supplementation of yeast culture had lack of response to animals that had been already adapted to high energy diet. Denev et al. (2007) stated that addition of yeas culture in the diet is less effective when animals are fed well-balanced diets that promote the stability of gastrointestinal microbial population and are more likely to have dramatic effects under conditions of dietary and environmental stress. Therefore, this result calls for consideration of the use of probiotics in feedlot production from the standpoint of improved performance.

\section{Carcass composition}

Although LWG was not affected by addition of combined probiotics (Saccharomyces cerevisae + Candida utilis) + herbs, beef cattle in this experiment showed an increase in the percentage of carcass, dressing and meat in the treated animals (Table 3). In the previous experiment (Mahyuddin and Widiawati, 2010) using the same combination of yeasts and herbs, buffaloes showed no response on the above parameters. This is probably the first reported result where yeast supplementation in finishing diet has beneficial effect on carcass characteristics. The difference in response between cattle and buffalo may be attributed to a difference in the digestive physiology of the two species. Although buffaloes have a significantly higher bacterial number, cattle have a better digestive utilization of organic matter and cellulose on high concentrate diet than buffaloes (Puppo et al., 2002).

Supplementation of yeast in high concentrate diet, which could enhance bacterial growth, stabilize rumen $\mathrm{pH}$ and increased supply of bacterial protein to the host animal (see Chaucheryas-Durand et al., 2008) and together with a longer residence time of digesta in postruminal in cattle as compared to that in buffalo (Bartocci et al., 1997), is therefore speculated to cause a better nutrient partitioning towards meat production as observed in this experiment. Various experiment also showed no effect of yeast supplementation on carcass characteristic of goats (Whitley et al., 2009), lambs (Kawas et al., 2007a; Titi et al., 2008a) and steers (Mir and Mir, 1994; Hinmann et al., 1998; Gomes et al., 2009).

In this experiment, cattle supplemented with probiotics + herbs showed no difference with the control in percentage of bone, meat: bone ratio, percentage of body fat, back fat thickness and eye muscle area (EMA). There was also no difference in the composition of meat fat between the control and treatment (Table 4). In male buffalo (Mahyuddin and Widiawati, 2010) the same combination of yeast and herbs added to the finishing diet, resulted in increased percentage of bone, reduced percentage of meat: bone ratio, body fat and offal. There is no explanation may be offered except that difference in the results of those two experiments may be due to differences in the animal species used as mentioned above. Variable results were noticed in the effect of yeast culture on percentage of body fat. Haryanto (2000) found a reduction in body fat of lambs, whereas Titi at al. (2008a) found an increase in body fat content of goat offered yeast culture.

The percentage of offal is lower in treated animals than that in control (Table 3) and was primarily due to lower intestinal content (Table 5). In buffalo, these probiotics + herbs supplementation also reduced percentage of offal, however, the reduction was caused not only by decreased intestinal content but also decreased lung and lymph content (Mahyuddin and Widiawati, 2010).

There have been inconsistent results of feeding probiotics as feed additive. Examination of literatures reveals that the rate of inclusion varies considerably, as does the type of probiotic (bacterial or yeast based or combination), the diet (forage base or grain base or ratio of forage:grain) and the time when the probiotic is given, the animal model being used and also the environment. Furthermore, certain probiotics may produce optimal results at specific points in the growth of animals. All those aspects should be thoroughly examined, in order to obtain more consistent results from probiotic use.

Although the beneficial effect of a combination of yeast (Saccharomyces cerevisae + Candida utilis) and herbs was observed in this experiment (increased carcass, dressing and meat percentage), this finding should not be taken conclusively. The addition of herbs in this study may have confounding effects, therefore more trials with a large number of experimental animals should be carried out to look at the effect of yeast with or without herbs or using single yeast or combination of yeasts.

Research on the use of herbal medicine in livestock should also be continued, more studies on the content of active compounds and the dose requirement for certain disease prevention or therapy should be carried out. 
Table 4. Fat Composition (g/100g) of Meat

\begin{tabular}{lrrr}
\hline \multicolumn{1}{c}{ Parameter } & \multicolumn{1}{c}{ Control } & \multicolumn{2}{c}{ Treatment } \\
\hline Saturated fat & \multicolumn{1}{c}{$43.8 \pm 1.91$} & 43.9 & \pm 2.50 \\
Capric acid & $0.34 \pm 0.06$ & $0.32 \pm 0.11$ \\
Lauric acid & $1.02 \pm 0.09$ & $0.92 \pm 0.26$ \\
Miristic acid & $9.0 \pm 0.78$ & $7.56 \pm 1.72$ \\
Palmitic acid & $28.6 \pm 1.66$ & $29.8 \pm 2.06$ \\
Stearic acid & $3.7 \pm 0.57$ & $5.3 \pm 1.29$ \\
Unsaturated fat & $49.2 \pm 2.58$ & 44.7 & \pm 1.77 \\
Oleac acid & $48.3 \pm 2.53$ & 43.3 & \pm 2.34 \\
Linoleac acid & $2.3 \pm 0.31$ & 2.3 & \pm 0.62 \\
\hline
\end{tabular}

Table 5. The Offal Composition (kg)

\begin{tabular}{lcc}
\hline \multicolumn{1}{c}{ Parameter } & Control & Treatment \\
\hline Heart & $1.3 \pm 0.06$ & $1.7 \pm 0.44$ \\
Liver & $5.3 \pm 0.23$ & $4.7 \pm 0.33$ \\
Lung & $2.6 \pm 0.23$ & $2.4 \pm 0.11$ \\
Limph & $1.1 \pm 0.15$ & $0.9 \pm 0.06$ \\
Renal & $1.0 \pm 0.11$ & $0.8 \pm 0.35$ \\
Intestine & $7.9 \pm 0.47^{\mathrm{a}}$ & $4.1 \pm 0.35^{\mathrm{b}}$ \\
Rumen & $9.4 \pm 0.56$ & $9.5 \pm 0.77$
\end{tabular}

Mean values with different superscripts at the same row indicatesdiffer

significantly $(\mathrm{P}<0.05)$

\section{CONCLUSION}

Addition of a combination of yeast (Saccharomyces cerevisae + Candida utilis) and herbs in the finishing diet of cattle did not alter LWG and DMI, but increased percentage of carcass, dressing and meat. Except the percentage of offal, the percentage of bone, meat; bone ratio, percentage of body fat, by-product, back fat thickness and eye muscle area were not different between the treated and control animal. The decrease in offal (\% BW) was due to a reduction in intestine weight.

\section{REFERENCES}

AOAC. 1990. Official methods of analysis. $14^{\text {th }}$ Ed. Assoc. Off. Anal. Chem., Arlington, VA.

Bartocci, S., A.Amici, M.Verna, S.Terramocci and F. Martillotti. 1997. Solid and fluid passage rate in buffalo, cattle and sheep fed diet with different forage to concentrate ratio.
Livestock Production Sci. 52:201-208

Beauchemi, K. A., W.Z.Wang, D. P. Morgavi, G.R.Ghorbani, W.Kautz and J.A.Z. Leedle. 2003. Effects of bacterial-fed microbial and yeast on site and extent of digestion, blood chemistry, and subclinical acidosis in feedlot cattle. J. Anim. Sci. 81:1628-1640

Cabrera, E. J. I., M. G. D. Mendoza, I. E. Aranda, C. Garcia-Bojalili and G.R. Barcena, J.J.A. Ramos. 2000. Saccharomyces cerevisae and nitrogenous supplementation in growing steers grazing tropical pastures. Anim. Feed Sci.Technol. 83(1):49-55

Chaucheryas-Durand, F., N. D.Walker and A. Bach. 2008. Effects of active dry yeasts on the rumen microbial ecosystem: Past, present and future. Anim.Feed Sci.Technol. 145: 5-26

Denev, S. A., Tz.Peeva, P. Radulova, P. Stancheva, G. Staykova, G. Beev, P. Todorova and S. Tchobanova. 2007. Yeast cultures in ruminant nutrition. Bulgarian $\mathrm{J}$. Agric.Sci. 13:357- 374

Erasmus, L. J., P. M, Botha and A. Kistner. 1992. Effect of yeast culture supplementation on production, rumen fermentation and duodenal nitrogen flow in dairy cows. J. Dairy Sci. 75:3056-3065.

Gomes, R. C., P. R. Lena, S.L. Silva, M. T. Antunes and C. F. Guedes. 2009. Carcass quality of feedlot finished steers fed yeast, monensin and the association of both additives. Arq. Bras. Med. Vet. Zootec 6 (3):648-654

Haddad, S. G. and S. N. Goussous. 2005. Effect of yeast culture supplementation on nutrient intake, digestibility and growth performance of Awassi lambs. Anim.Feed Sci.Technol. 118:343 - 348

Haryanto, B. 2000. Penggunaan probiotik dalam pakan untuk meningkatkan kwalitas karkas dan daging domba. J. Ilmu Ternak dan Veteriner. 5 (4):224 - 228

Hinman, D. D., S. J. Sorensen and P. A. Momont. 1998. Effect of yeast culture on steer performance, apparent diet digestibility and carcass measurements when use in a barley and potato finishing diet. The professional Anim. Scientist. 14:173- 177

Jouany, J. P. and D. P. Morgavi. 2007. Use of 'natural' products as alternatives to antibiotic feed additives in ruminant production. Animal. 1(10): 1443-1466

Kawas, J. R., R. Garcia-Castillob, F. GarzaCazaresa, H. Fimbres-Durazob, E. Olivares- 
Saenza, G. Hernande-Vidalb and C. D. Luc. 2007a. Effects of sodium bicarbonate and yeast on production performance and carcass characteristics of light weight lambs fed finishing diet. Small Ruminant Research. 67(2):157- 163

Kawas, J. R., R. Garcia-Castillo, H. FimbresDurazo, F. Garza-Cazares, J. F. G. Hernández-Vidal, E. Olivares-Sáenz and C.D. Lu. 2007b. Effects of sodium bicarbonate and yeast on nutrient intake, digestibility, and ruminal fermentation of light-weght lambs fed finishing diet. Small Ruminant Research. 67(2-3):149- 156

Krehbiel, C. R., R.A. Britton, D.L. Harmon, T.J. Wester and R. A. Stock. 1995. The effects of ruminal acidosis on volatile fatty acid absorption and plasma activities of pancreatic enzymes in lambs. J. Anim. Sci. 73:31113121.

Mahyuddin, P. and Y. Widiawati. 2010. Effect of combined (Saccharomyces cesrevisae + Candida utilis) + herbs on carcass characteristics of swamp buffalo. Animal Production. 12 (2):1-5

Mir, Z. and P. S. Mir. 1994. Effect of the Addition of Live Yeast (Saccharomyces cerevisiae) on growth and carcass quality of steers fed highforage or high-grain giets and on feed digestibility and In situ degradability. J. Anim. Sci. 1994. 72:537-545

Newbold, C. J., R. J. Wallace and F. M. McIntosh. 1996. Mechanisms of action of the yeast Saccharomyces cerevisiae as a feed additive for ruminants. Br. J. Nutr. 76(2): 249-261.

Newbold, C. J., F.M.McIntosh and R. J Wallace. 1998. Changes in the microbial population of a rumen simulating fermenter in response to yeast culture. Can. J. Anim. Sci. 78: 241-244

Puppo, S., S. Bartocci, S. Terramoccia, F. Grandoni and A. Amici. 2002. Rumen microbial counts and in vivo digestibility in buffaloes and cattle given different diets. Animal Science. 75:323-329

Ramirez, J. F., S. Medina and N. Garcia. 2007. Effects of the supplementation with yeast (Saccharomyces cerevisae) on weight gain and development of water buffalo calves. Italy J. Anim. Sci. 6 (suppl 2):505-507

Steel, R. G. D and J. H. Torrie. 1980. Principles and Procedures of Statistics. McGraw-Hill Book Co.Inc.New York

Tilley, J. M. A. and R. A. Terry. 1963. A two-stage technique for the in vitro digestion of forage crops. J. Brit. Grassland. 18:104

Titi, H. H., R.O. Dmour and A.Y. Abdullah. 2008a. Growth performance and carcass characteristics of Awassi lambs and Shami goat kids fed yeast culture in their finishing diet. Anim.Feed Sci.Technol. 142: 33-43

Titi, H. H., A.Y. Abullah, W. F. Lubbadeh and B. S. Obeitdah. 2008b. Growth and carcass characteristics of mail dairy calves on a yeast culture supplemented diet. South African J.Anim.Sci. 38(3): 174-183

Tripathy, K. K. and S. A. Karim. 2010. Effect of individual and mixed yeast culture feeding on growth performance, nutrient utilization and microbial protein synthesis in lambs. Anim. Feed Sci.Technol. 155(2):163-171

Whitley, N. C., D. Cazac, B. J. Rude, D. JacksonO'Crien and S. Parveen. 2009. Use of commercial probiotic supplement in meat goats. J. Anim. Sci. 87:723-728 